\title{
PENINGKATAN KOMPETENSI GURU MELALUI PEMBELAJARAN PETA KONSEP (MIND MAP)
}

\author{
Dasmo $^{1}$, Dandan Luhur Saraswati², Indica Yona Okyranida ${ }^{3}$ \\ ${ }^{1,2,3}$ Pendidikan Fisika, Fakultas Matematika dan Ilmu Pengetahuan Alam, Universitas Indraprasta PGRI
}

\begin{abstract}
Abstrak
Penyamaan persepsi (konsep) antara pengajar dan anak didik sangat penting dalam pembelajaran. Kegiatan ini dapat dilakukan sedari awal dalam pembelajaran dalam kelas. Pengajar menyampaikan persepsinya berupa konsep-konsep materi pelajaran yang akan disampaikan sehingga anak didik dapat mengetahui arah/alur pelajaran yang akan dipelajarinya. Pemahaman konsep yang benar dan sinkron antara pengajar dan anak didik diharapkan mampu membuat pembelajaran dalam kelas berjalan secara efektif dan efisien. Kegiatan pengabdian kepada masyarakat "PKM Mts Hidayatul Anam di Jakarta Selatan" ini bertujuan untuk memberikan pemahaman pentingnya pemberian peta konsep dalam proses belajar mengajar sehingga guru mampu menyusun peta konsep materi pelajaran sebagai sebuah instrument penting dalam pembelajaran. Metode yang digunakan dalam kegiatan ini adalah dengan pelatihan, pendampingan, dan diskusi. Pelatihan dilakukan dengan cara memberikan informasi mengenai model pembelajaran peta konsep serta praktik mengajar dengan model peta konsep. Guru juga dilatih untuk merancang dan membuat model pembelajaran peta konsep. Kegiatan ini berjalan dengan lancar, terlihat antusias guru yang semangat dalam mengikuti kegiatan pelatihan ini.
\end{abstract}

Kata Kunci: Kompetensi Guru, Peta Konsep

\begin{abstract}
Equalization of perceptions (concepts) between teachers and students is very important in learning. This activity can be done from the beginning in classroom learning. Teachers convey their perceptions in the form of subject matter concepts to be conveyed so that students can know the direction / flow of the lesson to be learned. Understanding the correct and synchronous concepts between teachers and students is expected capable to make learning in class run effectively and efficiently. Community service activities "PKM MTs Hidayatul Anam in South Jakarta" aims to provide an understanding of the importance of providing concept maps in the teaching and learning process so that teachers are capable to compile concept maps of subject matter as an important instrument in learning. The method used in this activity is by training, assistance, and discussion. The training is conducted by providing information about the concept map learning model and teaching practices with the concept map model. Teachers are also trained to design and create concept map learning models. This activity ran smoothly, and seemed enthusiastic about the teacher's enthusiasm in joining this training activity.
\end{abstract}

Keywords: Teacher Competencies, Mind Map

Correspondence author: Dasmo, amo0903unindra@gmail.com, Jakarta, Indonesia

This work is licensed under a $C C-B Y-N C$ 


\section{PENDAHULUAN}

Dalam proses pendidikan (khususnya pendidikan formal), cara pandang seorang guru (pengajar) merupakan faktor yang penting dalam menentukan arah pembelajaran atau transfer ilmu pengetahuan dari pengajar kepada peserta didiknya. Stimulus pembelajaran merupakan sebuah usaha yang digunakan untuk memperoleh respon sesuai dengan tujuan awal pembelajaran (Saraswati dkk, 2019:411). Persepsi pengajar akan mempengaruhi proses pembelajaran dalam kelas. Berbeda pandangan antara pengajar dan anak didik akan memberikan hasil pandangan yang berbeda. Seorang guru akan sangat terbantu apabila menggunakan pemahaman yang benar mengenai ilmu yang akan disampaikannya.

Sangat penting untuk menyamakan persepsi (konsep) antara pengajar dan anak didik. Kegiatan ini dapat dilakukan sedari awal dalam pembelajaran dalam kelas. Pengajar menyampaikan persepsinya berupa konsep-konsep materi pelajaran yang akan disampaikan sehingga anak didik dapat mengetahui arah/alur pelajaran yang akan dipelajarinya. Pemahaman konsep yang benar dan sinkron antara pengajar dan anak didik diharapkan mampu membuat pembelajaran dalam kelas berjalan secara efektif dan efisien.

Berdasarkan hasil wawancara dengan Kepala MTs Hidayatul Anam Jakarta Selatan diperoleh informasi bahwa sebagian besar guru masih menggunakan metode pembelajaran secara konvensional. Selain itu, dalam mengajar guru cenderung langsung menjelaskan pada topik pembahasan pem-belajaran. Hanya sebagian kecil guru yang menjelaskan terlebih dahulu melakukan apersepsi berupa peta konsep materi pembelajaran yang akan diberikan. Seperti yang telah dikemukakan sebelumnya bahwa apersepsi atau penyamaan persepsi sangat berguna untuk menyamakan gelombang frekuensi antara guru dan peserta didik. Koneksi ini sangat penting agar guru dan peserta didik memiliki pemahaman yang sama terhadap materi yang akan dibahas.

Peta konsep (mind map) adalah sistem penyimpanan, penarikan data, dan akses yang luar biasa untuk perpustakaan raksasa, yang sebenarnya ada dalam otak Anda yang menakjubkan (Buzan, 2013:12). Sementara Jansen (2002:95) menyatakan bahwa mind map (peta pikiran) sangat bermanfaat untuk memahami materi, terutama materi yang telah diterima oleh siswa dalam proses pembelajaran. Mind map bertujuan membuat materi pelajaran terpola secara visual dan grafis yang akhirnya dapat membantu merekan, memperkuat, dan mengingat kembali informasi yang telah dipelajari.

Riswanto dan Dasmo (2015:105) dari hasil penelitiannya menyimpulkan bahwa, terdapat perbedaan hasil belajar IPA yang signifikan antara peserta didik yang belajar menggunakan metode pembelajaran mind map dengan yang menggunakan metode pembelajaran konvensional dan hasil belajar IPA peserta didik yang belajar menggunakan metode pembelajaran mind maping lebih besar daripada yang belajar menggunakan metode pembelajaran konven-sional.

Kusuma (2015) menunjukkan manfaat pengunaan mind map adalah mampu memperlancar pengucapan kosa kata pada siswa tunarungu. Penggunaan mind map juga dapat meningkatkan motivasi belajar siswa. Hal ini telah dibuktikan melalui penelitian yang dilakukan oleh (Tapantoko, 2011) dengan langkah-langkah: (1) Mempelajari konsep suatu materi pelajaran, (2) Menentukan ide-ide pokok secara berkelompok, (3) Membuat atau menyusun peta pikiran mengunakan media Lembar Kegiatan Siswa (LKS), dan (4) Presentasi kelompok di depan kelas. 
Berbagai manfaat dapat diambil dari penerapan mind map dalam pembelajaran, namun demikian masih dijumpai pada beberapa kesulitan para pengajar dalam membuat peta konsep materi pelajaran. Pengajar telah menyusun silabus dan rencana pembelajaran, akan tetapi masih sering dijumpai tidak mencantumkan peta konsep dalam pembelajaran. Kebiasaan yang sering dilakukan adalah pengajar langsung memberikan judul materi pelajaran untuk selanjutnya menyampaikan materi secara beruntut. Kebiasaan ini terjadi bukan karena tidak paham mengenai materi pelajaran yang akan disampaikan, tetapi lebih disebabkan karena kurangnya ketrampilan pengajar dalam membuat peta konsep yang menarik.

Berdasarkan analisis situasi tersebut, tim ingin melakukan suatu kegiatan pengabdian kepada masyarakat "PKM MTs Hidayatul Anam di Jakarta Selatan" yang bertujuan untuk memberikan pemahaman pentingnya pemberian peta konsep dalam proses belajar mengajar sehingga guru mampu menyusun peta konsep materi pelajaran sebagai sebuah instrument penting dalam pembelajaran.

\section{METODE PELAKSANAAN}

Kegiatan pengabdian kepada masyarakat ini dilaksanakan pada bulan Maret sampai dengan Juli 2019. Tempat pelaksanaan dilakukan di MTs Hidayatul Anam. Sekolah tersebut berada di Jl. Jambu No. 1 RT/RW 005/010 Kelurahan Jati Padang, Pasar Minggu, Jakarta Selatan, DKI Jakarta. Peserta dalam kegiatan pengabdian kepada masyarakat ini adalah semua guru mata pelajaran pada sekolah mitra. Metode kegiatan yang akan digunakan meliputi pengamatan (observasi), wawancara, do-kumentasi, sosialisasi, pelatihan, dan monev (monitoring dan evaluasi). Pengamatan (observasi) dan wawancara dilakukan untuk mengetahui perma-salahan mitra. Dokumentasi digunakan untuk mendukung kegiatan pengabdian masyarakat yang dilaksanakan berkaitan dengan masalah yang diteliti.

Pelaksanaan kegiatan ini dilakukan dalam tiga tahap, yaitu tahap persiapan, pelaksanaan, dan evaluasi.

1. Tahap pertama adalah tahap persiapan. Dalam tahap ini tim melakukan survei pendahuluan untuk mengetahui kondisi target kegiatan dengan menganalisis kondisi tempat yang akan digunakan, kondisi peserta yang akan diberikan pelatihan, dan menyusun rancangan kegiatan yang akan dilakukan.

2. Tahap kedua yaitu tahap pelaksanaan. Pada tahap ini tim memberikan pelatihan bagi para pengajar agar dapat menyusun peta konsep yang benar dan menarik sehingga berkesan pada peserta didik dan praktik langsung.

3. Tahap ketiga adalah evaluasi. Evaluasi kegiatan ini dilakukan terhadap proses kegiatan. Evaluasi berkaitan selama kegiatan berlangsung dari tahap persiapan sampai tahap pelaksanaan, yang meliputi keadaan sekolah, kehadiran peserta pelatihan, antusias peserta saat mengikuti kegiatan, dan saran atau kritik terhadap kegiatan.

Adapun diagram alir untuk kegiatan pengabdian kepada masyarakat ditunjukkan pada Gambar 1. 


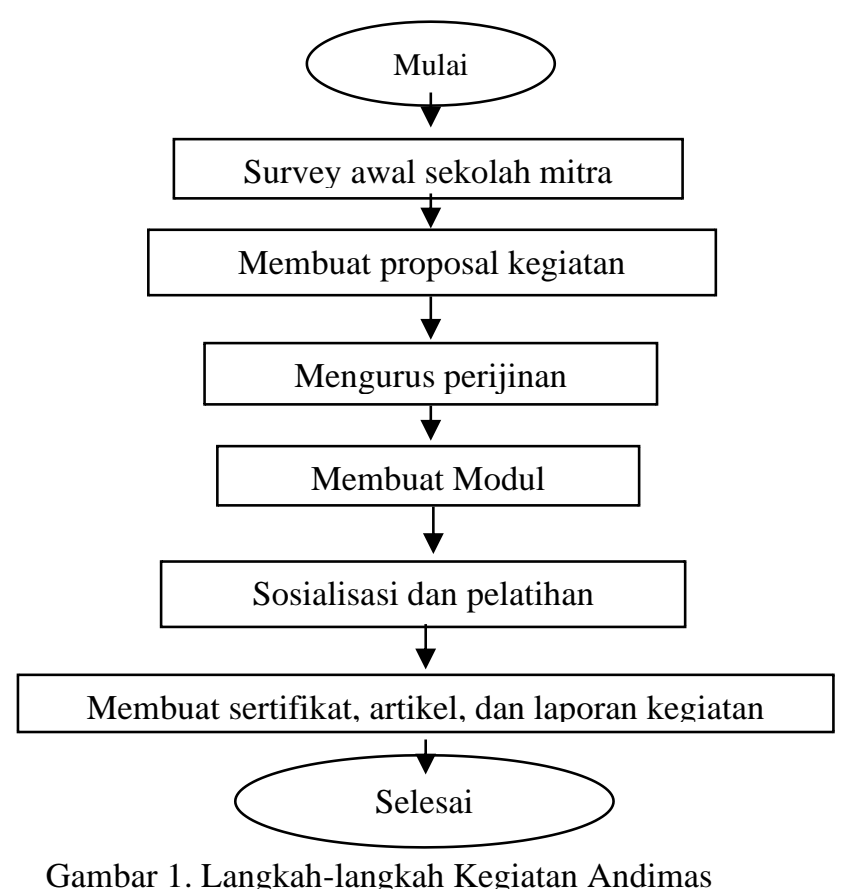

\section{HASIL DAN PEMBAHASAN}

Program pengabdian kepada masyarakat ini telah dilaksanakan di Mts Hidayatul Anam, Kelurahan Jati Padang, Pasar Minggu, Jakarta Selatan, DKI Jakarta. Program ini bertujuan untuk memberikan pemahaman pentingnya pemberian peta konsep dalam proses belajar mengajar sehingga guru mampu menyusun peta konsep materi pelajaran sebagai sebuah instrument penting dalam pembelajaran.

Realisasi kegiatan ini dilakukan dalam tiga tahap, yakni tahap persiapan, pelaksanaan dan evaluasi. Tahap pertama adalah tahap persiapan. Pada tahap ini tim melakukan survei pendahuluan bulan April 2019 untuk mengetahui kondisi pada mitra dengan menganalisis kondisi tempat yang akan digunakan, kondisi peserta yang akan diberikan perlakuan (seluruh guru) dan menyusun rancangan kegiatan yang akan dilakukan. Tahap persiapan selanjutnya tim menyiapkan bahan presentasi, lembar instrumen model pembelajaran peta konsep, modul pembuatan peta konsep, sarana dan prasarana untuk melengkapi kegiatan pelatihan seperti laptop dan LCD proyektor untuk pemaparan materi.

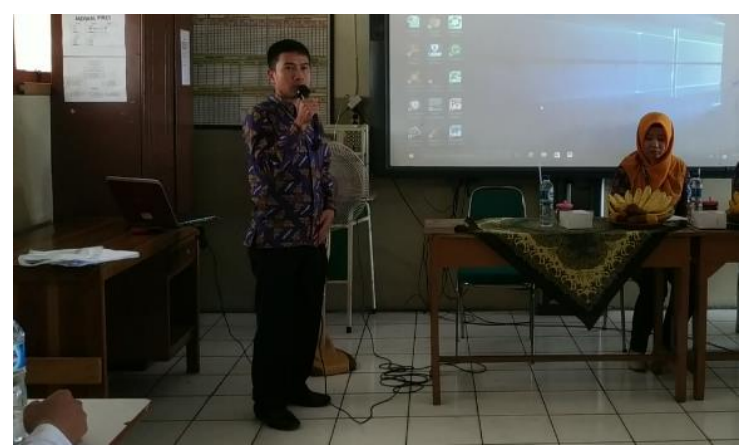

Gambar 2. Pemaparan Materi Model Pembelajaran Peta Konsep 
Tahap selanjutnya adalah tahap pelaksanaan. Pada tahap ini tim melakukan pelatihan terhadap kepala sekolah dan guru yang terdaftar di Mts Hidayatul Anam Pasar Minggu dalam mengimplementasikan model pembelajaran peta konsep. Peserta pelatihan adalah kepala sekolah, perwakilan yayasan, dan seluruh guru di Mts Hidayatul Anam yang berjumalah 20 orang. Akan tetapi, pada pelaksanaan kegiatan tidak semua guru dapat hadir. Peserta pelatihan yang hadir dalam kegiatan berjumlah 14 peserta. Kegiatan abdimas dilaksanakan selama tiga hari yaitu dari tanggal 10 - 12 Juni 2019. Sebelum pelaksanaan abdimas yaitu pada tanggal 5 Juni 2019, tim mengadakan rapat persiapan abdimas di Laboratorium Fisika UNINDRA. Pada tanggal 8 Juni 2019 tim ke sekolah untuk koordinasi dengan kepala sekolah dan perwakilan yayasan tentang jadwal dan kesiapan pelaksanaan abdimas.

Pada hari pertama pelaksanaan abdimas tanggal 10 Juni 2019 kegiatan abdimas berupa sosialisasi tentang model pembelajaran peta konsep yang dibawakan oleh Dandan Luhur Saraswati, M.Pd, Si. Kegiatan abdimas ini dibantu oleh 5 orang mahasiswa pendidikan fisika yaitu Delia Achadina Putri, Muhamad Yusup, Mutiara Sarazwati, Eppin Tambunan, dan Pia Saragih. Pada hari pertama, guru diberikan materi tentang pentingnya peta konsep dalam pembelajaran. Setelah itu, guru diminta untuk merancang model pembelajaran peta konsep sesuai dengan contoh-contoh yang disediakan dengan materi sesuai dengan mata pelajaran yang diajarkan.

Kegiatan berlangsung diawali dengan presentasi dari tim mengenai penguatan kreativitas dalam rangka pencapaian hasil belajar yang optimal. Kemudian dilanjutkan dengan pemaparan tentang konsep peta konsep dalam pembelajaran serta pelatihan dan pendampingan dalam pembuatan rencana pelaksanaan pembelajaran. Selama kegiatan berlangsung guru sangat antusias mengikutinya dengan banyak mengajukan pertanyaan untuk hal yang belum dipahami. Pada hari pertama kegiatan ini dihasilkan RPP model pembelajaran berbasis peta konsep buatan guru, yang mana kemudian akan dipraktikan pada hari ketiga nantinya.

Kemudian pada hari kedua tanggal 11 Juni 2019 berupa pelatihan membuat dan menyusun model pembelajaran peta konsep, yakni guru membuat peta konsep dari materi pelajaran sesuai mata pelajaran yang diampu. Guru diberikan kebebasan untuk berkreasi dalam membuat peta konsep tersebut. Dari hasil kegiatan ini terlihat terjadinya perbedaan kreativitas guru dalam membuat peta konsep dalam pembelajaran. Terdapat guru yang mampu menuangkan ide-ide ke dalam peta konsep sehingga peta konsep yang dibuat menarik dengan berbagai warna untuk mempermudah pemahaman. Akan tetapi, ada juga guru yang hanya membuat peta konsep secara biasa. Kondisi ini kemudian dievaluasi oleh tim dengan cara memberikan reward kepada guru yang telah membuat peta konsep secara baik dan menarik. Sementara guru yang membuat peta konsep biasa-biasa saja, dilakukan pendampingan sehingga mampu memperbaiki hasil pekerjaaanya.

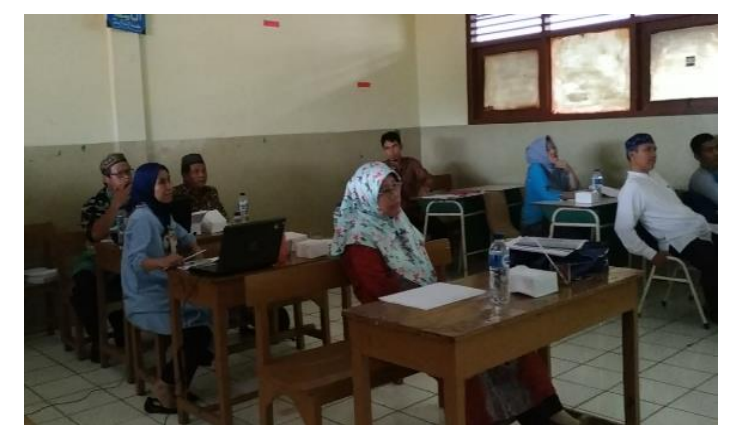

Gambar 3. Peserta Pelatihan Pembelajaran Peta Konsep 
Pada hari ketiga kegiatan abdimas dilakukan tanggal 12 Juni 2019 yang berisi tentang praktik pengajaran dengan pembelajaran peta konsep. Guru-guru berlatih mengajar dengan pembelajaran peta konsep yang dilakukan secara peer teaching. Antusias guru sangat baik, terlihat guru semangat mengajar dengan pembelajaran peta konsep. Pada tahap ini, guru yang mampu menampilkan performance terbaik diberikan reward oleh tim abdimas.

Tahap terakhir adalah tahap evaluasi. Pada tahap evaluasi tim juga menganalisis kegiatan selama pelatihan. Evaluasi ini tim datang ke sekolah pada tanggal 27 Juni 2019 untuk memonitoring kegiatan pembelajaran peta konsep dan wawancara ke guru apakah guru sudah menerapkan pembelajaran peta konsep di sekolah apa belum.

Peta konsep pada dasarnya model pembelajaran yang sudah lama dikenal. Akan tetapi, tidak semua guru paham akan manfaat model ini. Kecenderungan guru, masih menggunakan model yang simple dan mudah digunakan tanpa harus pusing memikirkan dan memersiapkan pembelajaran di rumah, yakni dengan menerapkan model pembelajaran ceramah. Model ini paling umum digunakan karena tidak membutuhkan persiapan yang terlalu rumit. Model pembelajaran peta konsep sendiri membutuhkan kreativitas dalam pelaksanaannya. Mind map merupakan istilah teknik pemetaan pikiran untuk membantu membuka seluruh potensi dan kapasitas otak yang masih tersembunyi. Pemetaan pikiran ini akan melibatkan kedua sisi otak secara bersamaan, yaitu otak kanan dan otak kiri. Metode ini mempermudah memasukan informasi kedalam otak dan untuk kembali mengambil informasi dari dalam otak.

Pelatihan ini berusaha untuk memberikan pemahaman dan bagaimana menerapkan model pembelajaran peta konsep di Mts Hidayatul Anam, Pasar Minggu. Kegiatan yang dilaksanakan selama 3 hari ini diharapkan dapat memberikan kontribusi kepada guruguru agar peserta didiknya mampu mengoptimalkan kinerja otak kanan dan otak kirinya sehingga pada akhirnya mampu meningkatkan hasil belajarnya. Seperti yang dikatakan oleh Jansen (2002:95) bahwa mind map (peta pikiran) sangat bermanfaat untuk memahami materi, terutama materi yang telah diterima oleh siswa dalam proses pembelajaran. Mind map bertujuan membuat materi pelajaran terpola secara visual dan grafis yang akhirnya dapat membantu merekan, memperkuat, dan mengingat kembali informasi yang telah dipelajari.

Kegiatan pelatihan ini sedikit banyak telah membuka pemahaman guru tetang pentingnya model pembelajaran yang menarik bagi peserta didik. Pemahaman itu terlihat dari antusiasme guru dalam mengikuti pelatihan dan berusaha untuk menampilkan karya terbaiknya. Kreativitas yang ditunjukkan merupakan langkah awal yang baik untuk dapat diterapkan dalam pembelajaran di kelas. Para guru juga melakukan diskusi dengan tim jika ada hal-hal yang masih bingung dalam pembelajaran peta konsep.

Hasil produk kegiatan ini berupa RPP pembelajaran peta konsep, instrumen, dan contoh-contoh peta konsep yang bisa digunakan dalam proses belajar mengajar di kelas. Dengan adanya kegiatan ini sangat membantu guru dalam pembelajaran peta konsep yang sesuai dengan trend pembelajaran di Indonesia saat ini.

\section{SIMPULAN}

Secara keseluruhan kegiatan pengabdian mayarakat yang dilakukan di Mts Hidayatul Anam, Pasar Minggu berjalan dengan baik. Guru-guru sangat antusias mengikuti acara demi acara yang diberikan oleh tim. Dengan kegiatan pelatihan seperti 
ini ternyata guru memiliki antusiasme yang tinggi dalam implementasi model pembelajaran peta konsep. Kegiatan ini telah mampu memberikan pemahaman pentingnya pemberian peta konsep dalam proses belajar mengajar sehingga guru mampu menyusun peta konsep materi pelajaran sebagai sebuah instrument penting dalam pembelajaran.

\section{DAFTAR PUSTAKA}

Buzan, T. (2013). Buku Pintar Mind Map. Jakarta: PT. Gramedia Pustaka Utama.

Jensen, E. dan Makowitz, K. (2002). Otak Sejuta Gygabite: Buku Pintar Membangun Ingatan Super. Bandung : Kaifa.

Syam, N., \& Ramlah, R. (2015). Penerapan Model Pembelajaran Mind Mapping Dalam Meningkatkan Hasil Belajar Pada Mata Pelajaran Ilmu Pengetahuan Sosial Siswa Kelas IV SDN 54 Kota Parepare. Publikasi Pendidikan, 5(3).

Kusuma, N. A., Irhandayaningsih, A., \& Kurniawan, A. T. (2015). Analisis Penggunaan Metode Mind Mapping Untuk Meningkatkan Kemampuan Membaca Pemahaman (Studi Kualitatif Siswa Tunarungu SD Kelas V Di Slb Negeri Semarang). Jurnal Ilmu Perpustakaan, 4(2), 29-38.

Riswanto, H., \& Dasmo, D. (2015). Upaya Meningkatkan Hasil Belajar Ilmu Pengetahuan Alam (IPA) dengan Metode Pembelajaran Mind Map. Formatif: Jurnal Ilmiah Pendidikan MIPA, 5(2).

Saraswati, D. L., Pratama, D., dan Putri, D. A. (2019). Pemanfaatan Wayang sebagai Media Pembelajaran. Prosiding Diskusi Panel Nasional Pendidikan Matematika, Jakarta: 24 Juli 2019. Hal. 411-416

Tapantoko, A. a. (2011). penggunaan Metode Mind Map untuk Meningkatkan Motivasi Belajar Siswa Dalam Pembelajaran Matematika Siswa Kelas VIII SMP Negeri 4 Depok. Yogyakarta: Universitas Negeri Yogyakarta 